\title{
Editorial
}

\section{DISCURSO INAUGURACIÓN DEL XXXI CONGRESO CHILENO DE OBSTETRICIA Y GINECOLOGÍA}

(23 de noviembre de 2007, Viña del Mar, Chile).

Creo necesario en vez de relatar los logros de mi directorio en estos dos últimos años, hacer una reflexión profunda. A raíz de una solicitud para escribir una editorial en una revista internacional he querido expresar, a título personal, algunos pensamientos que tal vez puedan representarlos.

La medicina, ciencia inexacta, arte y destreza que se adquiere con la experiencia del ejercicio y la madurez, que se alcanza a través del tiempo, nos tiene en una frontera del conocimiento apasionante, fantástica, emocionante e inimaginable, soñadas por tantas generaciones de médicos y científicos.

Las ciencias entre ellas la genética y la biología molecular nos han llevado a develar la secuencia del genoma humano, y a encontrarnos con verdades insospechadas.... "somos tan cercanos al gusano de la seda, al genoma del ratón y tenemos diferencias mínimas con nuestros parientes los primates". Para que decir cuan diferente es la raza blanca, de la negra y la asiática... "una sátira a la vanidad humana"..., tantas luchas por la discriminación racial, tantas muertes irracionales. Ni que decir de la clonación terapéutica.... iqueremos jugar a ser dioses y co-creadores a diestra y siniestra sin medir sus consecuencias!

Yo creo que el conocimiento y la sabiduría nos llevará al uso adecuado de estos avances para la raza humana y nuestros hermanos menores los animales y plantas. La reproducción de seres vivos a partir de ovocitos vitrificados con estudios genéticos pre-implantación capaces de diagnosticar enfermedades y potenciales dificultades futuras, nos abre increíbles oportunidades terapéuticas para mejorar nuestra calidad de vida.

El trabajo minucioso sin cesar de tantos centros de investigación e instituciones científicas, nos han permitido conocer las etapas que hemos recorrido desde el momento exacto de la fecundación y las vicisitudes de tan osada travesía de los gametos para llegar al momento culmine, de tener toda la potencialidad del ser en una sola célula.

El estudio de las células totipotenciales y pluripotenciales nos han llevado a conocer como se forman estirpes celulares tan específicas como las células neuronales, células hematológicas, células cardiacas, fibroblastos, etc. A través del estudio de los genes se ha develado como se desarrollan células específicas y su comportamiento, pero lo más increíble es el descubrimiento de genes capaces de desdiferenciar células tan específicas como una célula de la piel y transformarla en una célula pluripotencial, ¿es posible retroceder a gameto?, que a su vez podrían reproducir un nuevo ser humano, cerrando el círculo de la vida... jsorprendente!, jacaso estamos en presencia del conocimiento de la eterna juventud!

Sin embargo, también hoy siglo 21... "una mujer muere cada minuto por parto en el mundo"..., y el $99 \%$ de las muertes ocurren en países en desarrollo. Sabemos con certeza las causas de estas pérdidas dolorosas y lo más increíble que la mayoría son absolutamente prevenibles y con bajos costos. Aun más tenemos mujeres con partos abandonados, catastróficos, en mujeres,.... "perdón, niñas mujeres"..., dejadas a su suerte y luego portadoras de fístulas que van dejando su huella maloliente en su caminar, discriminadas hasta la muerte en vida, como seres desechables y como escoria de la raza humana jhasta cuando!

¡Como es posible que aún seres humanos no cuenten con agua potable viviendo en zonas donde las temperaturas se acercan a los $50^{\circ} \mathrm{C}$ ! Existen en la actualidad tribus americanas y africanas que viven en la prehistoria, sin saber que existen hombres llamados "civilizados" que han ido depredando el planeta hasta un punto de casi no retorno, que hemos provocado cambios climáticos con consecuencias insospechadas. Se nos derriten los polos produciendo cambios geográficos, hemos contaminado los mares y océanos, destruyendo una parte importante de nuestra propia cadena alimenticia. ¿Donde están los líderes y sabios? ¿No les interesa detener estos acontecimientos? ¡Ya sé, son otras las generaciones que lo sufrirán! ¿Tal vez no lograrán fama, ni poder, ni premios Nobeles por trabajar como tantos misioneros anónimos?

Nos maravillamos de los grandes avances de la ciencia y la tecnología y que pasa con "el desarrollo espiritual y del crecimiento interno de nuestrageneración" ¿Cuantos Einstein, Newton, Buda, Jesús hemos perdido en el tiempo por no acudir en ayudas de los mas desposeídos? ¡No habremos perdidos 
una cantidad enormes de genes necesarios para el desarrollo armónico de toda la humanidad! ¿Los podremos recuperar?

Afortunadamente, tenemos instituciones como la Federación Internacional de Ginecología y Obstetricia ( FIGO), Organización Mundial de la Salud (OMS), Organización Panamericana de la Salud (OPS), por nombrar solo algunas, que nos muestran la cruda realidad ¡Que vergüenza!.. Y que nos instan a trabajar incesantemente para que algún día podamos decir nunca jamás.

Los países desarrollados han comprometido parte de su ingreso bruto para ir a paliar en parte esta impactante realidad. Todos los esfuerzos que realizan distintos programas internacionales como el Programas Fístula, Maternidad e Infancia Segura, Alarm, Cáncer uterino, etc., nos compromete a poner todos nuestros esfuerzos para alcanzar el éxito y mejorar la calidad de vida de nuestras hermanas.

Debemos cuidar y conservar el pool over de genes de la humanidad para seguir asombrándonos de las maravillas de la ciencia ¿Es posible?, sin duda alguna.

Chile, en la década de los cincuenta del siglo pasado se encontraba en la miseria sanitaria con una mortalidad materna e infantil de las más altas del mundo, con expectativas de vida no superior a los 50 años, con una tasa de fecundidad de 5 a 6 hijos por pareja. La necesidad de obra de mano barata en regiones rurales para el cultivo de materias primas era imperiosa. La migración hacia los centros urbanos especialmente por la industrialización, cambió radicalmente el panorama. En la actualidad, mostramos al mundo índices de país desarrollado, como una mortalidad materna de 1,4 por 10.000 nacidos vivos, mortalidad infantil de 7 por mil nacidos vivos, mortalidad neonatal de 4 a 5 por mil nacidos vivos, tasa de fecundidad de 1,8 y expectativas de vida para la mujer de 81 años, atención profesional del parto de 99,9\%, solo en medio siglo, jincreíble!, sin ser autocomplaciente queda mucho por trabajar.

¡Qué permitió este cambio tan drástico! La introducción de la planificación familiar en la década de los 60, los programas de alimentación complementaria a la embarazada y a la infancia, permitieron el descenso impresionante de la mortalidad materna por aborto y la disminución de la mortalidad infantil por desnutrición y diarreas. La disminución de la tasa global de fecundidad nos ha llevado a niveles peligrosos que nos impiden renovar nuestra propia pirámide poblacional ¡Qué contradicción! Nos enfrentamos a la misma problemática que han sufrido países desarrollados, alcanzamos niveles de expectativas de vida para las mujeres de 81 años y de 75 años para los varones. Nos espera una gran tarea sobretodo en relación a políticas de salud pública frente al envejecimiento de nuestra población. ¡Tendremos al menos que reflexionar como afrontar estos nuevos desafíos!

Si pudiéramos ser un espejo para otros países tendríamos que decir que los programas de planificación familiar han sido un factor clave para la disminución de la mortalidad por aborto séptico. Este es un hecho que se repite en la historia de todos los países desarrollados. La planificación familiar gratuita al alcance de todos, sin restricción, nos ayudó además a la pesquisa del cáncer cérvico uterino a través del control periódico en el momento de la entrega de los métodos disponibles. No olvidemos que "muere una mujer cada dos minutos en el orbe por esta lacra que es absolutamente prevenible y curable". También hemos mejorado en este campo de la medicina chilena, pero aún se muere una mujer cada 12 horas en nuestro país por esta enfermedad maligna ¡Será la vacuna contra el papiloma virus la panacea!, en todo caso un avance alentador.

Lo más trascendente a mi juicio han sido las políticas de salud, estables a lo largo del tiempo, independiente de los vaivenes políticos y el compromiso de los médicos de mi país que han subsidiado por años la salud de todos mis compatriotas, ejerciendo un verdadero apostolado durante muchas décadas, jvaya a todos ellos mi admiración y gratitud!

Contamos con grandes aliadas, que son un ejemplo para el mundo y me refiero a las matronas, con su trabajo silencioso y perseverante en los lugares más apartados e inhóspitos de nuestra geografía, con una entrega digna del más profundo respeto y admiración.

Nos queda mucho por hacer, persisten aún desigualdades dolorosas, una distribución vergonzosa del ingreso per cápita que debemos corregir. Es posible sin titubeos canalizar recursos que reportarían aun resultados más óptimos. Sin embargo, seguirán conviviendo realidades tan disímiles como avances sensacionales de la ciencia a favor de pocos y una realidad de miseria y hambre para muchos. Podemos y debemos cambiar la historia, no dejemos de soñar por un mundo mejor de paz y oportunidades para todos.

Quiero dar las gracias a todos mis colegas por permitirme servir a esta prestigiosa institución.

Dr Eghon Guzmán B. Presidente. Sociedad Chilena de Obstetricia y Ginecología. 